\title{
Medievalista
}

Online

$27 \mid 2020$

Número 27

\section{A diplomacia e os diplomatas na baixa Idade Média portuguesa (1431-1475)}

Diplomacy and diplomats in the late Portuguese Middle Ages (1431-1475)

Duarte Maria Monteiro de Babo Marinho

\section{OpenEdition}

Edição electrónica

URL: http://journals.openedition.org/medievalista/2940

ISSN: $1646-740 X$

\section{Editora}

Instituto de Estudos Medievais - FCSH-UNL

Refêrencia eletrónica

Duarte Maria Monteiro de Babo Marinho, «A diplomacia e os diplomatas na baixa Idade Média portuguesa (1431-1475) », Medievalista [Online], 27 | 2020, posto online no dia 01 janeiro 2020, consultado o 02 janeiro 2020. URL : http://journals.openedition.org/medievalista/2940

\section{(c) (7) \&}

Mediavalista está licenciado com uma Licença Creative Commons - Atribuição-NãoComercial 4.0 Internacional. 
Título / Title (Português e Inglês): A diplomacia e os diplomatas na baixa Idade Média portuguesa (1431-1475) / Diplomacy and diplomats in the late Portuguese Middle Ages (1431-1475)

Autores) / Author(s): Duarte Maria Monteiro de Babo Marinho

Afiliação institucional / Institutional affiliation (Universidade, Faculdade, Departamento ou Unidade de Investigação / University, Faculty, Department or Research Centre):

Centro de Estudos da População, Economia e Sociedade, Faculdade de Letras da Universidade do Porto

Código postal / Postcode; Cidade / City; País / Country: 4150-564 Porto, Portugal ORCID: https://orcid.org/0000-0002-0202-495X

Fonte: Medievalista [Em linha]. Direc. Bernardo Vasconcelos e Sousa. Lisboa: IEM. Disponível em:

http://www2.fcsh.unl.pt/iem/medievalista/MEDIEVALISTA27/marinho2707.html ISSN: 1646-740X

DOI: $10.4000 /$ medievalista.2940

Data recepção do artigo / Received for publication: 12 de Setembro de 2018

Data aceitação do artigo / Accepted in revised form: 20 de Setembro de 2019 


\section{Resumo}

Temos como principal objetivo proceder a uma reflexão de conjunto sobre os homens que davam corpo à diplomacia régia portuguesa entre 1431 e 1475. Assim, para além de apontarmos algumas linhas de força relativas aos membros constituintes das embaixadas portuguesas, nomeadamente no que se refere à composição social destas, às características dos agentes diplomáticos e às estratégias do monarca para o seu recrutamento, procuraremos destacar algumas questões como a aquisição de competências e a duração de carreiras.

Palavras-chave: Diplomacia, Embaixadores, Idade Média, Perfis sociais, Elites medievais.

\section{Abstract}

Our main objective is to carry out an overall reflection on the men who formed the Portuguese royal diplomacy between 1431 and 1475. Therefore, in addition to pointing out some lines of force regarding the constituent members of the Portuguese embassies, like the composition the characteristics of diplomatic agents and the monarch's strategies for recruitment, we will seek to highlight certain issues such as the acquisition of skills and the duration of careers.

Keywords: Diplomacy, Ambassadors, Middle Ages, Social profiles, Medieval elites. 


\section{A diplomacia e os diplomatas na baixa Idade Média portuguesa (1431-1475) / Diplomacy and diplomats in the late Portuguese Middle Ages (1431-1475)}

\section{Duarte Maria Monteiro de Babo Marinho}

\section{Introdução}

O estudo da diplomacia medieval desde há muitos anos que vem atraindo a atenção dos historiadores a nível mundial ${ }^{1}$. Porém, devido a uma renovação de paradigmas historiográficos, essa realidade não foi constante: durante algumas décadas do século passado a Historiografia optou por não se dedicar, aprofundadamente, ao estudo de temas relacionados com a História da Diplomacia. Tratou-se de uma opção motivada pelo «desinteresse por questões relacionadas com a história factual, política e dos grandes homens» $^{2}$. Somente com o surgimento da terceira fase dos Annales essa tendência começou a inverter-se, permitindo «um retorno ao político, que se viria a efetivar nos anos de 1980 e a consolidar nas décadas seguintes» ${ }^{3}$. Com efeito, a observação de Néstor Vigil Montes confirma essa realidade. De acordo com as suas palavras, o estudo da diplomacia medieval revelou-se «una de las temáticas que en los últimos años ha

\footnotetext{
${ }^{1}$ MARINHO, Duarte de Babo - "Os agentes diplomáticos da Baixa Idade Média portuguesa (1431-1474): uma elite ao serviço da Coroa". História: Revista da Faculdade de Letras da Universidade do Porto, 7/2 (2017), p. 11.

${ }^{2}$ MARINHO, Duarte de Babo - "Recensão de Diplomatie et «Relations Internationales» au Moyen Âge (IXe-XVe siècle)", História: Revista da Faculdade de Letras da Universidade do Porto, 9/1 (2019), p. 235. ${ }^{3}$ MARINHO, Duarte de Babo - "Recensão de Diplomatie et «Relations Internationales» au Moyen Âge (IXe-XVe siècle)"..., p. 235.
} 
resurgido en la historiografia política medieval $[\ldots] \gg{ }^{4}$.

Esse ressurgimento também pode observar-se em Portugal. Após algumas décadas de modestas e parcelares publicações científicas a respeito de temas de diplomacia medieval $^{5}$, os historiadores portugueses passaram a seguir de perto as linhas de investigação propostas pela historiografia internacional ${ }^{6}$. Entre essas propostas historiográficas destacamos, por exemplo: i) os avanços fulcrais na Nova História da Diplomacia, realizados por John Watkins ${ }^{7}$; ii) e as considerações a respeito das redes de contacto entre diplomatas, apresentadas por Isabella Lazzarini ${ }^{8}$. Esta nova realidade começou a desenvolver-se nos finais da década de 2000 e início da seguinte, como se pode comprovar por intermédio da organização de vários colóquios em Portugal, dedicados à diplomacia medieval ${ }^{9}$, e pela publicação de abundante literatura a respeito

\footnotetext{
${ }^{4}$ VIGIL MONTES, Néstor - "A modo de introducción: nuevos caminos de la historiografía sobre la diplomacia medieval". In Comunicación política y diplomacia en la Baja Edad Media [ Em linha]. Dir. Néstor Vigil Montes. Évora: Publicações do Cidehus, 2019. [Consultado a 1 de Julho de 2019]. Disponível em https://books.openedition.org/cidehus/7438.

5 BRANCO, Maria João; FARELO, Mário - "Diplomatic Relations: Portugal and the Others". In MATTOSO, José (dir.) - The Historiography of Medieval Portugal: c. 1950-2010. Lisboa: Instituto de Estudos Medievais, 2011, pp. 231-259.

${ }^{6}$ A nível internacional destaca-se, entre outros, BECEIRO PITA, Isabel - "La tendencia a la especialización de funciones en los agentes diplomáticos entre Portugal y Aragón (1412-1465)". In El Poder Real en la Corona de Aragón. XV Congreso de Historia de la Corona de Aragón. Vol. 2. Zaragoza: Gobierno de Aragón, 1994, pp. 441-455. Da mesma Autora veja-se "La consolidación del personal diplomático entre Castilla y Portugal (1392-1455)". In III Jornadas Hispano-portuguesas de Historia Medieval. La Península Ibérica en la Era de los Descubrimientos (1391-1492). Vol. 2. Sevilla: Consejería de Cultura. Junta de Andalucía, 1997, pp. 1735-1744. "La importancia de la cultura en las relaciones peninsulares (siglo XV)". Anuario de Estudios Medievales 29 (1999), pp. 79-104. Finalmente, atente-se a PÉQUIGNOT, Stéphane Au nom du roi. Pratique diplomatique et pouvoir durant le règne de Jacques II d'Aragon (1291-1327). Madrid: Bibliothèque de la Casa Velázquez, $2009 \mathrm{e}$, do mesmo Autor, "Les diplomaties occidentales, XIII $\mathrm{XV}^{\mathrm{e}}$ siècles, dans les relations diplomatiques au Moyen Âge". In Formes et enjeux. Paris: Publications de la Sorbonne, 2011, pp. 47-66. MOEGLIN, Jean-Marie e PÉQUIGNOT, Stéphane (dir.) - Diplomatie et «Relations Internationales» au Moyen Âge (IXe-XVe siècle). Paris: Press Universitaires de France, 2017.

${ }^{7}$ WATKINS, John - "Toward a New Diplomatic History of Medieval and Early Modern Europe". Journal of Medieval and Early Modern Studies [Em linha] 38/1 (2008), pp. 1-14. [Consultado a 8 de Outubro de 2019]. Disponível em https://read.dukeupress.edu/jmems/issue/38/1.

${ }^{8}$ LAZZARINI, Isabella - Communication \& Conflict. Italian Diplomacy in the Early Renaissance, 13501520. Oxford: University Press, 2015, pp. 76-78.

${ }^{9}$ Sem a preocupação de sermos exaustivos, referimo-nos a alguns eventos realizados em Portugal recentemente: Colóquio X Internacional Corte e Diplomacia na Península Ibérica (séculos XIII-XVIII). Faculdade de Letras da Universidade de Lisboa, 13-14 de julho de 2016. Encontro Internacional Comunicação política e diplomacia no final da Idade Média. Universidade de Évora, 17-18 de novembro de 2016. Splendid Encounters VI. Correspondence and Information Exchange in Diplomacy (1300-1750). Universidade Nova de Lisboa, 28-30 de setembro de 2017. No entanto, é digno de nota mencionar a grande atividade a este nível nos países francófonos.
} 
do tema ${ }^{10}$.

Com efeito, este artigo insere-se na linha de investigação que tem vindo a desenvolverse nos últimos anos a propósito da diplomacia portuguesa. Tencionamos, desta forma,

${ }^{10}$ Relativamente a Portugal veja-se, por exemplo, LALANDA, Maria Margarida - "A política externa de D. Afonso IV (1325-1357). Arquipélago. História 11 (1989), pp. 107-151. FARELO, Mário - "La représentation de la couronne portugaise à Avignon et ses agents (1305-1377)". Anuario de Studios Medievales, 40/2, pp. 723-763. SANTOS, Maria Alice - A sociologia da representação políticodiplomática no Portugal de D. João I. Lisboa: Universidade Aberta, 2015. Tese de Doutoramento. MARINHO, Duarte de Babo - "A ação diplomática de Pedro Gonçalves de Malafaia na libertação do infante D. Pedro de Aragão (1432): antecedentes e significados”. Revista Portuguesa de História 46 (2015), pp. 83-96. Do mesmo autor vd. Os embaixadores portugueses nos reinos ibéricos (1431-1474). Um estudo sociodemográfico. Porto: Faculdade de Letras da Universidade do Porto, 2017, 2 vols. Tese de Doutoramento; "Os agentes diplomáticos da Baixa Idade Média portuguesa (1431-1474): uma elite ao serviço da Coroa". História: Revista da Faculdade de Letras da Universidade do Porto 7/2 (2017), pp. 1030; "Diplomacia visual na Baixa Idade Média portuguesa: os oficiais de armas". Medievalista [Em linha] 24 (julho-dezembro 2018). [Consultado a 12 Julho 2018] Disponível em http://www2.fcsh.unl.pt/iem/medievalista/MEDIEVALISTA24/marinho2404.html; “A atuação diplomática de Gomes Eanes e de Martim de Távora com vista à libertação do Infante D. Fernando (14391441)". Revista Mátria Digital 6 (2018), pp. 155-185; "Diplomacia e espionagem na baixa Idade Média portuguesa”. In VIGIL MONTES, Néstor (dir.) - Comunicación política y diplomacia en la Baja Edad Media [Em linha]. Évora: Publicações do Cidehus, 2019. [Consultado a 1 de Julho de 2019]. Disponível em https://books.openedition.org/cidehus/6946. FARIA, Diogo - "Uma embaixada portuguesa do final da Idade Média: de Lisboa a Roma, 1443-1445”. Anuario de Estudios Medievales 48/2 (2018), pp. 695-721. Do mesmo autor vd. "A participação de letrados laicos nas embaixadas portuguesas do final da Idade Média (1385-1495)”. In VIGIL MONTES, Néstor (dir.) - Comunicación política y diplomacia en la Baja Edad Media [Em linha]. Évora: Publicações do Cidehus, 2019. [Consultado a 12 Julho 2019]. Disponível em https://books.openedition.org/cidehus/7350; “«Todos hão de ficar cegos»: l'Italia di fine XV secolo osservata da un cardinale portoghese". Mediterranea - ricerche storiche Ano 14 (dezembro 2017), pp. 695706. LIMA, Douglas Mota Xavier de - “A política matrimonial de D. João I: um instrumento de afirmação dinástica. Portugal, 1387-1430". Roda da Fortuna. Revista Eletrônica sobre Antiguidade e Medievo 3/2 (2014), pp. 191-209. Do mesmo autor vd. "Novos olhares sobre a diplomacia medieva". Revista Transversos 3 (2015), pp. 77-91; A diplomacia portuguesa no reinado de D. Afonso V (1448-1481). Niterói: Universidade Federal Fluminense, 2016. Tese de Doutoramento; "Regal ceremonies and diplomatic practices. Contributions from the travel narratives from the 15th century". In VIGIL MONTES, Néstor (dir.) - Comunicación política y diplomacia en la Baja Edad Media [Em linha]. Évora: Publicações do Cidehus, 2019. [Consultado a 1 Julho 2019]. Disponível em https://books.openedition.org/cidehus/7453. FARIA, Tiago Viúla de - After Windsor: the politics of Anglo-Portuguese politics and their protagonists in the later middle ages. Oxford: Universidade de Oxford, 2013. Tese de Doutoramento. Do mesmo autor vd. "Por prol e serviço do reino? O desempenho dos negociantes portugueses do Tratado de Windsor e suas consequências nas relações com Inglaterra (1384-1412)". Actas das VI Jornadas luso-espanholas de Estudos Medievais. A Guerra e a Sociedade na Idade Média. Vol. 2. SPEM, 2009, pp. 209-227; "Tracing the 'chemyn de Portynlage': English Service and Servicemen in Fourteenth-Century Portugal". Journal of Medieval History 37/3 (setembro 2011), pp. 257-268. VIGIL MONTES, Néstor - "Los retos actuales de la diplomática desde la perspectiva ibérica: ampliación de los horizontes espaciales y cronológicos, nuevos campos de investigación, adaptación a las nuevas tecnologías”. Revista Portuguesa de História 49 (2018), pp. 99-124. Do mesmo autor vd. "«Tractados de pazes, aliança e concordia entre as duas coroas de Portugal e Inglaterra», un cartulario a comienzos del siglo XV para consolidar el alianza permanente más prolongada de la historia". Espacio, Tiempo y Forma. Revista de la Facultad de Geografia e Historia 32 (2019), pp. 469-498; "Diplomacia y diplomática: un análisis de las fuentes documentales de la diplomacia bajomedieval". In VIGIL MONTES, Néstor (dir.) - Comunicación política y diplomacia en la Baja Edad Media [Em linha]. Évora: Publicações do Cidehus, 2019. [Consultado a 1 Julho 2019]. Disponível em https://books.openedition.org/cidehus/6880. 
contribuir para esse debate historiográfico, colocando a tónica em importantes questões associadas à diplomacia quatrocentista portuguesa, nomeadamente entre os anos de 14311475. Com efeito, estes anos corresponderam a um período histórico-diplomático complexo. Dando continuidade a uma tendência iniciada no reinado de D. João I, Portugal afirmou-se internacionalmente, por intermédio de uma rede diplomática extremamente eficaz, responsável pela articulação e envio de um elevado número de embaixadas a várias unidades políticas, tanto na Europa como no Norte de África ${ }^{11}$. Ainda assim, apesar da monarquia portuguesa ter empreendido políticas diplomáticas eficazes, cujo objetivo principal foi alargar o seu leque de contactos externos, Luís Adão da Fonseca constata que esse período foi nitidamente dominado por umas oscilantes relações luso-castelhanas: ora de amizade, ora de inimizade ${ }^{12}$.

Perante o exposto, de várias questões que poderíamos colocar ao tema, optámos por abordar quatro aspetos essenciais. Primeiro, determinar a caracterização social dos diplomatas. Segundo, explorar as competências e os atributos desses homens. Terceiro, compreender os mecanismos de recrutamento e as instâncias do poder de onde eram originários. Quarto, debater a especialização dos diplomatas, destacando, neste ponto, os processos de aquisição de competências, a duração das carreiras ao serviço da diplomacia e o número de missões internacionais desempenhadas.

A resposta a estas questões baseia-se na releitura cuidadosa de fontes narrativas e epistolares. Em especial podemos destacar, entre outras tipologias, os registros das chancelarias régias de D. Duarte e de D. Afonso V e algumas cartas de instrução depositadas no Fundo Manizola da Biblioteca Pública de Évora (que recentemente foram objeto de um estudo aprofundado por Cristina Cunha, Paula Pinto Costa e Duarte Babo) ${ }^{13}$. Os dados recolhidos nesta documentação foram complementados por alguns trabalhos historiográficos pertinentes para o tema, dos quais destacamos a tese de doutoramento de

\footnotetext{
${ }^{11}$ GOMES, Saul António - D. Afonso V. O Africano. Mem Martins: Círculo de Leitores, 2006, pp. 113114.

${ }^{12}$ FONSECA, Luís Adão da - D. João II. Mem Martins: Círculo de Leitores, 2005, p. 143. ARAÚJO, Julieta - Portugal e Castela na Idade Média. Lisboa: Edições Colibri, 2009, p. 3.

${ }^{13}$ MARINHO, Duarte de Babo. COSTA, Paula Pinto. MARIA CRISTINA, Cunha - "Preparation of embassies and protocol followed by royal Portuguese ambassadors in late-medieval times". E-Journal of Portuguese History [Em linha] 1/17 (2019). [Consultado a 1 Julho 2019]. Disponível em https://www.brown.edu/Departments/Portuguese_Brazilian_Studies/ejph/forth.html.
} 
Duarte Babo, que nos fornece uma lista pormenorizada do pessoal diplomático enviado aos reinos ibéricos entre 1431-1474. Terminado o levantamento das informações documentais procuraremos identificar os diplomatas e sistematizar os dados biográficos referentes a esses homens, mediante a realização de catálogos prosopográficos. Na verdade, este método de trabalho permitiu-nos traçar o perfil colectivo de 54 indivíduos que compunham essa micro-sociedade ${ }^{14}$, considerando aspetos como as origens sociais, as instâncias onde eram recrutados e as qualificações académicas e culturais. Deste modo, é possível afirmar que um grande número de diplomatas de fins da Idade Média exercia um ou mais cargos de nomeação régia. Era nesses ofícios que, ao longo dos anos, estes homens faziam carreira e aperfeiçoavam competências o que os tornava depositários de memórias e conhecedores dos mais imbricados mecanismos burocráticos.

\section{A diplomacia portuguesa em finais da Idade Média}

A diplomacia constitui uma ramificação da Política Externa de um Estado, definindo-se como o conjunto de atuações de um embaixador (ou outro tipo de representante régio) ${ }^{15}$, sempre subordinadas às decisões da $\mathrm{Coroa}^{16}$. Contudo, na Idade Média, apesar da importância política das embaixadas e dos embaixadores, esta era uma prática ad hoc e, como tal, não representava uma profissão, o que contrastava com as demais atividades profissionais ligadas à administração régia. (Com exceção de algumas unidades políticas italianas, que em meados do século XV começaram a desenvolver a génese da diplomacia moderna ${ }^{17}$ ). Quer isto dizer que se constituíam embaixadas e recrutavam diplomatas por um tempo limitado, com a finalidade de tratar questões pontuais ou reforçar os laços entre soberanos ${ }^{18}$.

\footnotetext{
${ }^{14}$ Para as questões metodológicas associadas a este tema veja-se, entre outros, MONTEIRO, Nuno Gonçalo; CARDIM, Pedro - "La Diplomacia durante el Antiguo Régimen. Perfil sociológico y trayectorias". Cuadernos de Historia Moderna 30 (2005), pp. 7-40. MARINHO, Duarte de Babo - Os embaixadores portugueses..., vol. 1, pp. 80-111.

${ }^{15}$ MAGALHÃES, José Calvet de - A Diplomacia Pura. Lisboa: Bizâncio, 2005, p. 83.

${ }^{16}$ OLIVERA SERRANO, Cesar - "Servicio al rey y diplomacia castellana: Don Juan Manuel de Villena (1462)". Anuario de Estudios Medievales [Em linha] 25 (1995), pp. 463-488. Consultado a 12 de Julho de 2019]. Disponível em http://digital.csic.es/bitstream/10261/17263/1/20090717140926228.pdf.

${ }^{17}$ LAZZARINI, Isabella - Communication and Conflict...

18 MATTINGLY, Garrett - Renaissance Diplomacy. Baltimore: Penguin Books, 1964, p. 55. MENDONÇA, Manuela - "Diplomatas portugueses na costa africana (1434-1495): uma releitura de João de Barros". Mare Liberam: revista de história dos mares 10 (1995), pp. 341-353. BENNÀSSER, Pau "Negociar la paz en el siglo XIV". In COELHO, Maria Helena da Cruz; GOMES, Saúl António; RIBEIRO,
} 
Apesar da representação externa ser uma atividade circunstancial, os homens que ocupavam o ofício de diplomata eram escolhidos entre os mais competentes do Reino. Naquele tempo, somente os mais capacitados para determinado tipo de missão eram escolhidos, o que implicava uma meticulosa seleção. Este crivo que incidia sobre estas captações é compreensível: os diplomatas eram a voz do rei e o garante do prestígio do reino no exterior, e deles dependia o sucesso de uma missão.

Sendo assim, optava-se pelos homens que mais se adequavam a determinada missão, o que nos leva a pensar em áreas de especialização e de atuação diplomática ${ }^{19}$. Em paralelo, esses homens deviam respeitar os seguintes aspetos, alguns deles tidos em conta desde a Época Clássica: i) ser socialmente destacado; ii) conhecer regras de etiqueta e de precedência; iii) ter qualificações académicas (sobretudo Direito) ou culturais relevantes; iv) ser inteligente, hábil e paciente; e v) ser um notável orador.

Considerando o exposto, compreende-se que a preparação de uma missão diplomática era uma tarefa bastante complexa: exigia uma prévia e profunda análise de inúmeros dados, obtidos lícita ou ilicitamente (i.e., por intermédio da espionagem ${ }^{20}$ ). Cabe assinalar que era bastante comum os soberanos pedirem aos seus embaixadores para auscultarem e recolherem o máximo de informações nas suas deslocações ${ }^{21}$. Desta forma, os diplomatas aproveitavam a imunidade que lhes era garantida pelo ofício que desempenhavam e pela Corte visitada ${ }^{22}$, visto que "un souverain doit savoir recevoir les ambassadeurs envoyés par les Etats voisins" ${ }^{23}$. Todavia, este princípio nem sempre era respeitado ${ }^{24}$, como

\footnotetext{
Ângelo (ed.) - A Guerra e a sociedade na Idade Média. VI Jornadas luso-espanholas de estudos medievais. Vol. 2. Sociedade Portuguesa de Estudos Medievais, 2009, pp. 16-28.

${ }^{19}$ OLIVERA SERRANO, Cesar - "Servicio al rey y diplomacia castellana...", pp. 476-477, 481.

${ }^{20}$ MARINHO, Duarte de Babo - "Diplomacia e espionagem na baixa Idade Média portuguesa"..

${ }^{21}$ Esta problemática é explorada em MARINHO, Duarte de Babo, COSTA, Paula Pinto, MARIA CRISTINA, Cunha - "Preparation of embassies and protocol followed by royal Portuguese ambassadors in late-medieval times"...

${ }^{22}$ Veja-se o exemplo da carta de salvo-conduto que D. Afonso V atribuiu ao conde de Benavente, emissário do rei de Castela, a 28 de fevereiro de 1449: "E, porquanto a nos praz de sua vijmda, lhe damos, per esta nossa carta, nossa seguramça real, pera el e todos aqueles que lhe prouver comsigo trazer, da vijmda, estada e tornada" (MONUMENTA Henricina. Ed. António Joaquim Dias Dinis. Vol. 10. Coimbra: Comissão Executiva do V Centenário da Morte do Infante D. Henrique, 1960-1974, doc. 8); ou a carta que o mesmo monarca concedeu a um embaixador do rei de Tunes, garantindo-lhe que pode "ir e vir a este Reyno" em segurança (Arquivo Nacional da Torre do Tombo, Chancelaria de D. Afonso V, liv. 9, fl. 147).

${ }^{23}$ LEROY, Béatrice - Du France parler en politique. Aimer et devoir écrire aux souverains en Castille au $X V^{e}$ siècle. Limoges: Université de Limoges/Pulim, 2014, p. 82.

${ }^{24}$ PÉQUIGNOT, Stéphane - Au nom du roi ..., p. 177.
} 
provam algumas violações à imunidade de embaixadas portuguesas, como foi o caso da de Martim Mendes de Berredo, em $1458^{25}$.

Uma carta de instrução inédita, de 20 de abril de 1456, entregue por D. Afonso V a D. João Fernandes da Silveira ilustra bem aquele tipo de pedidos. Este embaixador, ao deslocar-se em missão diplomática à Santa Sé, deveria recolher o máximo de informações relativamente às forças de terra e mar dos reis cristãos (aliados) e dos turcos (inimigos) ${ }^{26}$. Recolhidas as informações pretendidas, o rei, em articulação com o Conselho Régio - e por vezes com as Cortes, como demonstra o estudo de Armindo de Sousa ${ }^{27}$ —, procedia à preparação de novas missões, das estratégias argumentativas e à redação das respetivas cartas de instrução. Tudo isto com o objetivo de desmerecer e refutar os argumentos dos diplomatas contrários, de forma a chegar a um acordo final e vantajoso para todos ${ }^{28}$. Exemplo da utilidade deste tipo de solicitações reflete-se na instrução que D. Afonso V entregou a Álvaro Lopes de Chaves, para ir em embaixada a Castela: essa carta foi redigida com base nas informações que Cide de Sousa trouxe no regresso de uma das suas deslocações àquele reino, no final da década de $1460^{29}$. Não surpreende, por tanto, que a diplomacia, tanto ontem como hoje, constitua uma atividade cúmplice do silêncio, mas também criadora de espaços de diálogo, nos quais o diplomata tentaria fazer jus à arte de negociar sem ser enganado ${ }^{30}$.

Além da preparação das cartas de crença, que acreditava e apresentava o diplomata junto da Corte visitada, e das cartas de instrução, onde se elencava pormenorizadamente toda a sua atuação, era essencial preparar a logística e o financiamento da embaixada, aspetos que recebiam a devida atenção por parte dos monarcas. Os procedimentos do rei D. João I, aquando da missão do prior do Hospital à Sicília referidos por Zurara, exemplificam o

\footnotetext{
${ }^{25}$ FERREIRA, Ana Maria - "O processo de Pedro Barreto contra Jean Forestier. Um episódio nas relações luso-francesas". Revisa da Faculdade de Letras de Lisboa 1 (1977), pp. 619-639.

${ }^{26}$ Biblioteca Pública de Évora, Fundo Manizola, Códice 177, fls. 24-29v. Trata-se de documentação inédita, publicada por MARINHO, Duarte de Babo - Os embaixadores portugueses... Vol. 2, p. 215-222.

${ }^{27}$ SOUSA, Armindo de - As cortes medievais portuguesas: 1385-1490. Vol. 2. Porto: INIC, 1990.

${ }^{28}$ MAGALHÃES, José Calvet de - A Diplomacia Pura..., pp. 158-159.

${ }^{29}$ CHAVES, Álvaro Lopes de - Livro de apontamentos (1438-1489). Códice 443 da colecção Pombalina da B. N. L. Ed. Anastácia Mestrinho Salgado e Abílio José Salgado. Lisboa: Imprensa Nacional-Casa da Moeda, 1984, p. 319.

${ }^{30}$ MENDONÇA, Manuela - "Portugal na Christiana Respublica". In SOARES, Nair de Nazaré Castro; LÓPEZ MOREDA, Santiago (ed.) - Génese e consolidação da Ideia de Europa. Idade Média e Renascimento. Vol. 4. Coimbra: Imprensa da Universidade de Coimbra, 2009, p. 73.
} 
primeiro destes aspetos ${ }^{31}$. Relativamente ao segundo, D. Afonso V foi responsável por uma determinação, datada de setembro de 1473, onde constam os montantes a atribuir a uma embaixada, que variavam em função dos destinos. Sendo assim, os “[...] Embaixadores, ou pesoas outras que per seu mandado forem a Espanha; a saber, Castela, Aragaõ, Navarra \&c [...]”, tinham direito a quantias monetárias distintas dos "Embaixadores, ou pesoas que forem per mandado do dito Senhor, como pasare[m], e sahiem fora da Espanha [... $]^{\prime 32}$.

\section{Caraterização social dos embaixadores}

Ao longo da Idade Média portuguesa a nobreza destacou-se como o grupo social predominante na diplomacia, principalmente quando o destino das missões diplomáticas era a Península Ibérica ${ }^{33}$. Dois fatores justificam a captação de nobres para essas missões. Em primeiro lugar, o prestígio que lhes conferiam: tratavam-se de cortesãos ambientados ao cerimonial palaciano e às suas precedências. Note-se que o prestígio geralmente ditava a boa ou má receção de uma embaixada, ou mesmo a sua rejeição. A título meramente ilustrativo (e um pouco deslocado da nossa baliza cronológica), a deslocação de Lourenço Martins a Inglaterra foi considerada uma missão fracassada devido à sua falta de prestígio. Por conseguinte, e na sequência de uma nova missão àquele reino, D. João I armou cavaleiro Lourenço Anes Fogaça antes de este partir ${ }^{34}$. Esta nobilitação promovida pelo monarca garantiu o prestígio essencial à missão e evitou um novo desaire diplomático.

Um segundo aspeto a considerar, embora menos conhecido, são as redes familiares dos diplomatas nos locais de destino, por se efetuarem de forma um tanto ou quanto sigilosa ${ }^{35}$. Porém, seriam extremamente úteis no desenvolvimento de canais políticos, ou pelo

\footnotetext{
${ }^{31}$ ZURARA, Gomes Eanes de - Crónica da tomada de Ceuta. Ed. Reis Brasil. Lisboa: Europa-América, 1992, cap. 80.

${ }^{32}$ LIVRO Vermelho de D. Afonso V. In Collecção de livros ineditos da Historia portuguesa dos reinados de D. Affonso V a D. João II. Ed. José Correia Serra. Lisboa: Academia Real das Sciencias, 1790-1793, vol. 3, doc. 26, pp. 467-468.

${ }^{33}$ LALANDA, Maria Margarida - "A política externa de D. Afonso IV...”, p. 137. MARINHO, Duarte de Babo - Os embaixadores portugueses..., Vol. 1, p. 95.

${ }^{34}$ RUSSELL, Peter - A intervenção inglesa na Península Ibérica durante a Guerra dos Cem Anos. Lisboa: Imprensa Nacional da Casa da Moeda, 2000, pp. 398-399.

${ }^{35}$ RODRIGUES, Ana Maria S. A. - "Casamentos régios na Idade Média: um feixe de problemas". In RODRIGUES, Ana Maria S. A.; SILVA, Manuela Santos; FARIA, Ana Leal de (coord.) - Casamentos da Família Real Portuguesa. Vol. 1. Lisboa: Círculo de Leitores, 2017, p. 41.
} 
menos, num primeiro momento, de compromissos e alianças sociais que constituiriam a base de negociações posteriores ${ }^{36}$. Depreende-se, assim, a existência de uma sobreposição de lógicas familiares e políticas no exercício da diplomacia. Efetivamente, segundo Ana Leal de Faria, “era frequente o recurso a canais paralelos de comunicação, mais íntimos e secretos, que escapavam às redes diplomáticas oficiais" ${ }^{37}$.

Várias embaixadas também contaram com a presença de homens dos médios e altos estratos da hierarquia eclesiástica, confirmando assim uma realidade transversal à Europa medieval ${ }^{38}$. No quadro político do século XV português, os clérigos encontravam-se, essencialmente, vocacionados para as embaixadas enviadas à Santa Sé, cenário principal de atividade diplomática europeia, não só pela sua importância no panorama político medieval $^{39}$, como pelo facto de ser o local mais ativo e bem informado da Europa ocidental. Para aí convergiam e daí fluíam as mais recentes informações políticas, militares, comerciais e religiosas. Desta forma, não estranhamos que os soberanos portugueses mantivessem constantes missões diplomáticas no papado, protagonizadas por membros do clero, com o objetivo de obterem informações vitais para os seus interesses $^{40}$. Ainda assim, é possível detetá-los, embora com menor expressividade, em missões a outras unidades políticas, como é o caso de Castela, Coroa de Aragão, Inglaterra e França ${ }^{41}$. De facto, a importância simbólica dos clérigos também era indispensável na assinatura de tratados diplomáticos, o que pode ajudar a justificar a sua presença em missões a outras Cortes que não a pontifícia, devido ao importante papel das celebrações litúrgicas que, por vezes, envolviam esses acontecimentos ${ }^{42}$.

Estudos até agora efetuados permitem-nos conhecer algumas condições que, até certo

\footnotetext{
${ }^{36}$ MARINHO, Duarte de Babo - Os embaixadores portugueses... Vol. 1, pp. 95-99.

${ }^{37}$ FARIA, Ana Leal de - "«Tu felix Austria nubes»". In RODRIGUES, Ana Maria S. A.; SILVA, Manuela Santos; FARIA, Ana Leal de (coord.) - Casamentos da Família Real Portuguesa. Vol. 1. Lisboa: Círculo de Leitores, 2017, p. 59.

${ }^{38}$ BRANCO, Maria João; FARELO, Mário - “Diplomatic Relations: Portugal and the Others”..., p. 248.

${ }^{39}$ NIETO SORIA, José Manuel - Iglesia y génesis del Estado Moderno en Castilla (1369-1480). Madrid: Editorial Complutense, 1993, pp. 17-22 e 292.

${ }^{40}$ Assim, e a título de exemplo, veja-se a carta que D. Afonso V escreve a João Fernandes da Silveira, mandando recolher informações junto da Santa Sé sobre os exércitos cristãos e muçulmanos, no contexto da "Cruzada contra o Turco" que se preparava (Biblioteca Pública Évora, Fundo Manizola, Códice 177, fl. $27 \mathrm{v}-28)$.

${ }^{41}$ MARINHO, Duarte de Babo - Os embaixadores portugueses... Vol. 1, p. 93 e Vol. 2, anexos 2A e 2B $\left(n^{\circ} 27,31,42,44,52\right.$ e 61$)$.

${ }^{42}$ MARINHO, Duarte de Babo - Os embaixadores portugueses... Vol. 1, p. 200.
} 
ponto, se revelam importantes para a escolha de determinados clérigos para o exercício diplomático. Portugal não constitui, a este nível, exceção. Assim, refira-se antes de mais a sua presença na Corte, o que lhes permitia conhecer os protocolos do meio cortesão e assegurar a proximidade ao rei, visível na circunstância de muitos serem confessores régios. Depois, mas não menos importante, possuíam competências académicas e literárias especialmente valorizadas neste contexto. Regra geral, os clérigos sabiam latim, oratória, retórica, Direito e Teologia. Compreende-se assim que os vários monarcas do século XV procurassem manter membros da Igreja nos seus círculos mais próximos.

Se a maior parte dos diplomatas ao serviço dos monarcas portugueses quatrocentistas eram nobres e clérigos, um número não negligenciável destes oficiais corresponde a uma categoria nebulosa de indivíduos. Queremos com isto dizer que apesar de serem abundantemente referidos nas fontes documentais não nos é possível determinar a sua ascendência, dada a pobreza de informações relativas a cada um deles. Frequentemente, os dados de que dispomos acerca destes homens são de índole académica, nomeadamente relacionados com a área do Direito ${ }^{43}$. Sabemos igualmente que alguns exerceram cargos de oficiais de $\operatorname{armas}^{44}$.

A diplomacia também contava com outro grupo bastante importante: os homens ligados à atividade comercial, e que muitas vezes podiam ser nobres, como é o caso de Leonel de Lima $^{45}$. De facto, a atividade mercantil proporcionava-lhes uma grande itinerância e a criação de vastas redes de contactos, que os mantinha a par das realidades políticas e sociais dos locais por onde passavam ${ }^{46}$. Deste modo, é compreensível que esses homens fossem captados inúmeras vezes de forma a representarem o reino internacionalmente, não só para mediarem um negócio diplomático, mas também para o transporte de missivas diplomáticas (aproveitando, assim, as suas rotas marítimas e redes de conhecimentos nos

\footnotetext{
${ }^{43}$ MARINHO, Duarte de Babo - Os embaixadores portugueses... Vol. 1, p. 90.

${ }^{44}$ MARINHO, Duarte Babo - "Diplomacia visual na Baixa Idade Média portuguesa: os oficiais de armas". Medievalista [Em linha] 24 (julho-dezembro 2018). [Consultado a 12 de Julho de 2018]. Disponível em http://www2.fcsh.unl.pt/iem/medievalista/MEDIEVALISTA24/marinho2404.html.

${ }^{45}$ MARINHO, Duarte de Babo - Os embaixadores portugueses... Vol. 2, fichas prosopográficas 5, 19, 25 , 28 e 39.

${ }^{46}$ PÉQUIGNOT, Stéphane - Au nom du roi..., p. 110. MIRANDA, Flávio - Portugal ant the Medieval Atlantic. Commercial Diplomacy, Merchants, and Trade, 1143-1488. Porto: Faculdade de Letras da Universidade do Porto, 2012. Tese de Doutoramento, pp. 180-209.
} 
locais de destino). Esta realidade converge para o que se sabe acerca deste grupo social: desde os finais do século XIV, e ao longo de toda a centúria de $\mathrm{XV}$, os mercadores ganharam um papel relativamente importante no palco da Diplomacia Internacional.

Exemplos desta realidade não faltam na História de Portugal ${ }^{47}$. Entre vários, o caso mais célebre é o de Afonso Martins Alho e o seu importante contributo para a assinatura do tratado de Windsor ${ }^{48}$. Mas, além da atividade diplomática deste homem, temos outros casos como, por exemplo, o de João da Barca, mercador e "apresentador" do infante D. Fernando $(O \text { Santo })^{49}$. Realçamos a atividade deste homem por ter participado em duas importantes missões diplomáticas: em 1441 dirigiu-se a Granada e a Marrocos, juntamente com um representante de Mohammed VIII para aí negociarem alguns aspetos acerca da libertação do referido infante ${ }^{50}$.

Diga-se que, com alguma frequência, os letrados também representavam o rei nas relações diplomáticas, mas não é possível identificá-los com um qualquer grupo social, pois em todos eles existiam homens com formação académica.

\section{Competências e atributos dos diplomatas}

Além de uma condição social prestigiante era necessário que um diplomata apresentasse outros pré-requisitos: sólida formação académica em Direito (Civil e/ou Canónico) ou em Teologia; cultura letrada relevante; e conhecimentos linguísticos, nomeadamente o latim, devido à sua grande preponderância nos tratados jurídicos medievais ${ }^{51}$. Estamos, assim, perante uma realidade que se afirmou ao longo de todo o século XV (embora a sua génese

\footnotetext{
${ }^{47}$ LALANDA, Maria Margarida - "A política externa de D. Afonso IV...”, pp. 107-151. MARINHO, Duarte de Babo - Os embaixadores portugueses..., Vol. 2, anexos 2A, no 21 e 2B, no 65 e 69.

${ }^{48}$ Por todos veja-se FONSECA, Luís Adão da - O essencial sobre o Tratado de Windsor. Lisboa: Imprensa Nacional-Casa da Moeda, 1986.

${ }^{49}$ ÁLVARES, Fr. João - Trautado da vida e feitos do muiito vertuoso Sr. Infante D. Fernando. In Obras de Frei João Álvares. Ed. Adelino Almeida Calado. Vol. 1. Coimbra: Imprensa da Universidade, 19591960, pp. 204-207.

${ }^{50}$ MARINHO, Duarte de Babo - "A atuação diplomática de Gomes Eanes e de Martim de Távora com vista à libertação do Infante D. Fernando (1439-1441)” ..., pp. 155-185.

${ }^{51}$ PÉQUIGNOT, Stéphane - Au nom du roi..., p. 97. CÓRDOVA MIRALLES, Álvaro Fernández de "Imagen de los Reyes Católicos en la Roma pontificia". En la España Medieval 28 (2005), p. 265. MARINHO, Duarte de Babo - Os embaixadores portugueses..., Vol. 1, p. 172 e Vol. 2, fichas prosopográficas $29,32,42,45$.
} 
remonte aos finais da centúria anterior) e que convergia com a realidade internacional e com as teorias defendidas pelo canonista quatrocentista Bernard du Rosier ${ }^{52}$. Um pouco por toda a Europa Ocidental é possível detetar estes doutos homens ao serviço de várias entidades políticas: os seus qualificados pareceres eram essenciais, tanto ao nível da política interna como da externa. Esta atuação permitia que estas personalidades se destacassem, tanto na sociedade do seu tempo como nas embaixadas ${ }^{53}$.

Não obstante, além de uma condição social prestigiante e de relevantes qualificações académicas, era ainda indispensável que um diplomata apresentasse determinadas virtudes cardeais e dotes de oratória. No que respeita às primeiras, definem-se de acordo com as seguintes expressões: discrição, prudência, honra, bondade, fidelidade e boa memória. Muitas destas qualidades eram semelhantes às exigidas aos bons conselheiros: "homens que saibam das coisas; ser bem entendidos e de bom siso; bom entendimento; captar as coisas; ser amigo do rei" ${ }^{54}$.

A prudência e a discrição eram faculdades de um diplomata de hábil paciência, o que permitia prever, evitar e solucionar, lúcida e subtilmente, possíveis contratempos que ocorressem durante as negociações ${ }^{55}$. Por sua vez, honra, bondade e fidelidade, constituem outro conjunto de requisitos referentes às virtudes de muitos diplomatas portugueses. Estas caraterísticas traduzem-se por credibilidade social, aspeto essencial ao desempenho de ofícios públicos, como era, inegavelmente, o de embaixador/agente

\footnotetext{
52 Não dispomos de dados que comprovem ou refutem o conhecimento deste tratado em Portugal. Vd. Biblioteca Nacional de França, Mss Lat 6020, fl. 45v-46. BECEIRO PITA, Isabel - "La consolidación del personal diplomático...", p. 1735-1474. RAMIREZ VAQUERO, Eloísa - "Estrategias diplomáticas de rey de Navarra en el tránsito al siglo XV". In XXXI Semana de Estudios Medievales. Pamplona: Gobierno de Navarra/Departamento de Cultura y Turismo/Institución Príncipe de Viana, 2005, p. 398.

${ }^{53}$ PÉQUIGNOT, Stéphane - Au nom du roi..., p. 172 e 193. MARINHO, Duarte de Babo - Os embaixadores portugueses..., Vol. 1, p. 209.

${ }^{54}$ ORDENAÇÕES Afonsinas. Ed. Mário Júlio de Almeida Costa e Eduardo Borges Nunes. $2^{\text {a }}$ Ed. Vol. 1. Lisboa: Fundação Calouste Gulbenkian, 1998, tít. 59. GILLI, Patrick - "Bernard de Rosier et les débuts de la réflexion théorique sur les missions d'ambassade". In ANDRETTA, Stefano; PÉQUIGNOT, Stéphane; WAQUET, Jean-Claude (dir.) - De l'ambassadeur. Les éscrits relatifs à l'ambassadeur et à l'art de négocier du Moyen Âge au début du XIX siècle [Em linha]. Roma: Publications de l'École française de Rome, 2016, p. 5 [Consultado a 12 Julho 2018]. Disponível em https://books.openedition.org/efr/2907.

${ }^{55}$ PÉQUIGNOT, Stéphane - "Les instructions aux ambassadeurs des rois d'Aragon (XIII- XV siècles). Jalons pour l'histoire de la fabrique d'une parole royale efficace". Cahiers d'études hispaniques médiévales 31 (2008), p. 34. VILLANUEVA MORTE, Concepción - "La correspondencia diplomática entre los embajadores del ducado de Milán y la corte de los reinos hispánicos en la segunda mitad del siglo XV". In Dossier la sociedad cortesana en la Península Ibérica (siglos XIV-XV): fuentes para su estudio. Casa de Velasquez, 2015, p. 160.
} 
diplomático ${ }^{56}$. Compreende-se, pois, que o rei os considerasse homens respeitadores e zelosos do seu real estado, bem como pelos vínculos existentes entre ambos. Rui Gomes de Alvarenga é um exemplo desta realidade, como comprova uma carta que $\mathrm{D}$. Afonso $\mathrm{V}$ lhe dirigiu. De acordo com as palavras do monarca, vemos que este indivíduo era um profissional cumpridor; e, por isso, merecedor da confiança régia: “conheço que sooes amigo teendes assaz de descriçom e saber ey por certo que amaaes muyto todo o que a meu estado e serviço perteence que sam huumas das principaaes que se rrquer ao bõo comselheyro" 57 .

A memória era outra qualidade apreciada num embaixador ${ }^{58}$, e que em muitas ocasiões garantia o êxito das missões. Um exemplo ilustrativo da necessidade de os diplomatas terem boa memória encontra-se no capítulo XVIII da Crónica da Tomada de Ceuta: o prior do Hospital faz uma descrição pormenorizada de memória da referida cidade, permitindo, assim, que o monarca elaborasse os planos de conquista. Ainda assim, uma boa memória teria pouca utilidade se o diplomata tivesse miopia intelectual e um instinto mal apurado: seria incapaz de compreender a multiplicidade de acontecimentos que se desenrolavam ao seu redor ${ }^{59}$.

Por último, mas não menos importante: os códigos de oratória. Trata-se de um aspeto muito valorizado por Rosier. Um bom diplomata evita lapsus linguae e sabe que é no início da exposição que cativará os ouvintes: para o fazer pode, entre outras hipóteses, elogiar honestamente a plateia, à semelhança do que fez Jean Jouffroy a D. Afonso $\mathrm{V}^{60}$.

Havia, pois, a preocupação de selecionar pessoas com dotes de oratória, que, por um lado, assegurassem eloquência e o respeito pelas regras discursivas, e, por outro, a capacidade de projeção adequada da voz ${ }^{61}$. Certamente era esse o caso de Vasco Fernandes de

\footnotetext{
${ }^{56}$ Biblioteca Nacional de França, Mss Lat 6020, fl. 48v.

${ }^{57}$ Biblioteca Nacional de Portugal, Maço 226, $\mathrm{n}^{\circ} 6$.

${ }^{58}$ MARINHO, Duarte de Babo - Os embaixadores portugueses..., Vol. 2, fichas prosopográficas 28, 41, $45,49$.

${ }^{59}$ RAMIREZ VAQUERO, Eloísa - "Estrategias diplomáticas de rey de Navarra... XV”, p. 381.

${ }^{60}$ RAMOS, Manuel - Orationes de Jean Jouffroy em favor do Infante D. Pedro (1449- 1450). Retórica e Humanismo cívico. Porto: Faculdade de Letras da Universidade do Porto, 2006. Tese de Doutoramento, p. 105 e seguintes.

${ }^{61}$ GILLI, Patrick - "Bernard de Rosier...”, p. 7-8.
} 
Lucena, Pedro Faleiro e D. Fernando de Castro. Do primeiro destaque-se a sua participação em importantes embaixadas de obediência à Santa Sé. Dos restantes há notícia de uma embaixada a Inglaterra e dos elogios de Henry IV à forma exemplar, clara e elegante como expuseram as questões a debater ${ }^{62}$.

\section{Recrutamento e instâncias de poder}

Ao contrário do que se passava na generalidade das restantes instâncias administrativas régias, a diplomacia não se afirmava como uma carreira; muito pelo contrário: tratava-se de um ofício esporádico e limitado no tempo. Em face desta realidade é essencial saber que estes "bons homens letrados, de sã consciência" 63 provinham, essencialmente, do Conselho (31\%), da Câmara Régia (25\%) e dos tribunais superiores $(24 \%)^{64}$. Era nestes locais que aprimoravam as suas competências e ganhavam visibilidade para o trato diplomático. Como nos recorda António Manuel Hespanha ${ }^{65}$, estamos na presença de uma elite não só imprescindível ao bom desempenho do funcionalismo régio, como dos homens mais aptos de um grupo a participar em embaixadas.

A presença de indivíduos provenientes dos organismos ligados à justiça reflete o grande prestígio social associado a essas funções e vinca a questão da formação em Direito e da eloquência jurídica. Estes aspetos ganham relevância nos finais do século XIV, outorgando, assim, aos diplomatas um papel preponderante na representação externa e nas questões político-diplomáticas ${ }^{66}$.

Fica assim evidente que a Coroa era extremamente seletiva em relação aos diplomatas: além de se rodear maioritariamente de uma camada social nobre e consideravelmente qualificada académica e culturalmente, também procurava recrutar esses indivíduos no

\footnotetext{
${ }^{62}$ MARINHO, Duarte de Babo - Os embaixadores portugueses..., Vol. 1, p. 256.

${ }^{63}$ SOUSA, Armindo de - As cortes medievais portuguesas..., Vol. 2, p. 458, nº 49.

${ }^{64}$ MARINHO, Duarte de Babo - Os embaixadores portugueses..., Vol. 1, p. 209 e 328.

65 HESPANHA, António Manuel - História das instituições: época medieval e moderna. Coimbra: Almedina, 1982, p. 345 e seguintes.

${ }^{66}$ AUTRAND, Françoise - "Office et officiers royaux en France sons Charles VI (1388-1413)". Revue Historique. 93e année, 242 (1969), pp. 49-64. CAÑAS GÁLVEZ, Francisco de Paula (2010) - "La diplomacia castellana durante el reinado de Juan II: la participación de los letrados de la cancelaría real en las embajadas regias". Anuario de Estudios Medievales 40/2 (2010), p. 292.
} 
seu círculo mais próximo. De facto, os cargos de aconselhamento pressupõem uma maior acuidade, pois destacam um saber prático adquirido e muito necessário aos conselhos e aos cargos políticos de topo; estes homens eram depositários da confiança régia, em virtude da proximidade que tinham ao rei, o que lhes garantia um maior entrosamento com os negócios mais sensíveis de cariz diplomático ${ }^{67}$.

Contudo, alguns diplomatas não se encontravam apenas relacionados com um único organismo da Cúria Régia. Frequentemente estavam associados a outras instâncias de poder. A título meramente ilustrativo, sublinhe-se os nomes de Diogo da Fonseca, João Fernandes da Silveira e Rui Gomes de Alvarenga, homens que apresentaram ligações ao Conselho, à Casa da Suplicação, à Casa do Cível e à Chancelaria ${ }^{68}$. Assim, partindo destes e de outros casos individuais, comprovou-se a existência de uma circulação de oficiais entre as diversas instituições do poder régio português. Itinerâncias deste género proporcionavam a estes homens, independentemente da sua experiência curricular, uma aprendizagem continua que incidia sobre múltiplos aspetos ${ }^{69}$.

\section{Agentes diplomáticos especializados?}

\section{Processo de aquisição de competências}

O que temos vindo a ser referir adquire uma maior dimensão quando se equaciona que, naquele tempo, não existia um organismo público dedicado exclusivamente à preparação dos diplomatas; e que estes dificilmente teriam contacto com uma literatura especializada a respeito do tema. Na verdade, o que garantia a preparação destes homens era: i) a experiência adquirida em missões diplomáticas anteriores; ii) as cartas de instrução de que se faziam acompanhar; iii) e o desempenho de um ofício no funcionalismo régio ${ }^{70}$,

\footnotetext{
${ }^{67}$ HOMEM, Armando Luís de Carvalho - "De João das Regras ao Conselho Régio: os legistas na afirmação da nova dinastia". In DOMINGUES, Francisco Contente; HORTA, José da Silva; VICENTE, Paulo David (org.) - D'aquém, d'além e d'Ultramar: homenagem a António Dias Farinha. Vol. 2. Lisboa: Universidade de Lisboa. Faculdade de Letras/Centro de História, 2015, pp. 1061-1074. MARINHO, Duarte de Babo Os embaixadores portugueses..., Vol. 1, pp. 171-183.

${ }^{68}$ MARINHO, Duarte de Babo - Os embaixadores portugueses..., Vol. 2, fichas prosopográficas 10, 21, 48.

${ }^{69}$ VAZ, Vasco Rodrigo dos Santos Machado - A boa memória do monarca. Os escrivães da Chancelaria de D. João I (1395-1433). Vol. 1. Porto: Faculdade de Letras da Universidade do Porto, 1995. Dissertação de Mestrado, pp.98-99.

${ }^{70}$ PÉQUIGNOT, Stéphane - Au nom du roi..., p. 39.
} 
embora este ponto nem sempre seja possível de determinar, por se desconhecer o ano de determinadas embaixadas ou porque uma missão deste género se tratou da única ligação de alguns destes homens à Corte ${ }^{71}$.

Como tal, é compreensível que tanto na diplomacia como nos restantes setores da administração régia, sempre que um monarca subia ao trono confirmava inúmeros cargos anteriormente exercidos, garantindo, assim, que afetava o mínimo possível o bom funcionamento do sistema ${ }^{72}$. Além disso, garantia a existência de um conjunto de servidores preparados e prestigiados, o que beneficiava não só a burocracia régia como a diplomacia.

A antiguidade destes funcionários régios demonstra a sua competência, maturidade, conhecimentos e as inúmeras aptidões técnico-práticas adquiridas ao longo do seu trajeto profissional $^{73}$. Já D. Afonso, $4^{\circ}$ conde de Ourém, a 4 de junho de 1433, expôs ao rei D. Duarte, a necessidade de nas embaixadas participarem "grandes pesoas" providas de assinalável entendimento, porque só assim os recetores da delegação "sentyam que pois taes pesoas emujaes que grande tençon tendes naquilo a que os mandaes"74.

Desta forma, compreende-se que a diplomacia se sujeitava aos conhecimentos dos homens que serviam o rei. O mesmo será dizer que o monarca dependia do horizonte e alcance da informação de cada diplomata, mas também da sua análise e do conhecimento das realidades recentes, bem como da destreza de cada um em usar essas informações em prol do bom serviço ao reino ${ }^{75}$.

\section{Duração das carreiras na Diplomacia}

\footnotetext{
${ }^{71}$ MARINHO, Duarte de Babo - Os embaixadores portugueses..., Vol. 2, fichas prosopográficas 2, 4, 7, 8, $10,11,13,14,18,23,36,37$ e 40.

${ }^{72}$ MOTA, Eugénia Pereira da - Do Africano ao Príncipe Perfeito: (1480-1483). Caminhos da burocracia régia. Vol.1. Porto: Faculdade de Letras da Universidade do Porto, 1989. Dissertação de Mestrado, p. 73 e 110.

73 DUARTE, Dom - Leal Conselheiro. Ed. Maria Helena Lopes de Castro e Afonso Botelho. Lisboa: Imprensa Nacional-Casa da Moeda, 1999, pp. 101-102. MARINHO, Duarte de Babo - Os embaixadores portugueses..., Vol. 1, p. 326.

${ }^{74}$ DUARTE, Dom - Livro dos conselhos de el-rei D. Duarte. Livro da Cartuxa. Ed. A. H. de Oliveira Marques e João José Alves Dias. Lisboa: Editorial Estampa, 1982, p. 71.

${ }^{75}$ PÉQUIGNOT, Stéphane - Au nom du roi..., p. 97.
} 
A duração das carreiras é uma questão de grande pertinência para o estudo das sociedades políticas medievais. A presença em ofícios régios, quer pela antiguidade, na maior parte dos casos, quer pela qualidade dos serviços prestados, explica a nomeação de alguns homens para a prática diplomática. Isto indicia uma maior especialização em determinadas matérias, à semelhança da restante Europa ocidental ${ }^{76}$.

Contudo, um exercício semelhante ao que outros historiadores realizaram quando analisaram o Desembargo e a Burocracia, torna-se impraticável para o estudo das carreiras na diplomacia medieval portuguesa. A explicação para esta impossibilidade reside no facto de, ao contrário dos serviços nos restantes departamentos da Cúria Régia, a diplomacia não constituía uma atividade autónoma e permanente, como já se referiu ${ }^{77}$.

Todavia, existem casos esporádicos de homens que atuaram como embaixadores permanentes de Portugal, mais precisamente junto da Santa Sé. Uma dessas personalidades é o abade D. Gomes que, devido à sua atuação como mediador dos interesses portugueses naquela Corte, é apontado como o nosso grande embaixador junto do sumo pontífice e considerado como uma das personagens-chave da política externa de então $^{78}$. Mas existem outros casos semelhantes aos do abade D. Gomes, como por exemplo, o de Nuno Fernandes Tinoco, o clérigo que mais tempo permaneceu em funções efetivas em Roma, i.e., entre os anos de 1458-1484, correspondentes aos pontificados de Pio II, Paulo II e Sisto IV ${ }^{79}$.

\section{Quantidade de missões desempenhadas}

\footnotetext{
${ }^{76}$ Por todos veja-se AUTRAND, Françoise; CONTAMINE, Philippe - "Naissance de la France: naissance de sa diplomatie. Le Moyen Âge". In Histoire de la diplomatie française. Du Moyen Âge à l'Empire. Vol. 1. Paris: Perrin, 2005, pp. 39-177.

${ }^{77}$ HOMEM, Armando Luís de Carvalho - "Diplomacia e diplomatas nos finais da Idade Média a propósito de Lourenço Anes Fogaça, chanceler-mor (1374-1399) e negociador do Tratado de Windsor”. In Actas do Colóquio Comemorativo do VI Centenário do Tratado de Windsor. Porto: Instituto de Estudos Ingleses da Faculdade de Letras da Universidade do Porto, 1988, p. 223. NOGALES RINCÓN, David - "La cultura del pacto en las relaciones diplomáticas luso-castellanas durante el periodo Trastámara (1369-1504)". En la España medieval 35 (2012), p. 138.

${ }^{78}$ Veja-se a recente publicação, anotada, de cerca de 550 documentos referentes ao Abade D. Gomes. Esta publicação conta com uma introdução e estudo relativo ao dito prelado, da autoria de Rita Costa Gomes. Vd. PORTUGUESE Abbot in Renaissance Florence. The letter collection of Gomes Eanes (1415-1463). Ed. Rita Costa Gomes. Firenze: Casa Editrice/Leo S. Olschki, 2017.

${ }^{79}$ MARINHO, Duarte de Babo - Os embaixadores portugueses..., Vol. 1, pp. 332-333.
} 
Para além da documentação avulsa, as listas de embaixadas que Jorge Faro publicou em as Receitas e Despesas da Fazenda Real são da maior importância para o estudo da quantidade de missões efetuadas entre 1431 e 1475. Contudo, esta última fonte documental levanta uma série de questões já referidas detalhadamente em outra ocasião ${ }^{80}$.

O cálculo da quantidade de missões desempenhadas é outra forma de considerar uma suposta especialização da diplomacia portuguesa. Porém, a limitação desse cálculo reside no facto do número de missões ser variável e depender muito dos homens envolvidos.

\begin{tabular}{|c|c|c|}
\hline \multicolumn{3}{|c|}{$\begin{array}{c}\text { Tabela 1 — Número médio de anos em contacto com } \\
\text { administração régia antes da primeira missão diplomática }\end{array}$} \\
\hline Período de tempo & Número de diplomatas & Percentual \\
\hline 1 a 4 anos & 10 & $18 \%$ \\
\hline 5 a 9 anos & 10 & $18 \%$ \\
\hline 10 a 19 anos & 20 & $38 \%$ \\
\hline 20 a 29 anos & 4 & $8 \%$ \\
\hline 30 ou mais anos & 1 & $2 \%$ \\
\hline Ind. & 9 & $16 \%$ \\
\hline
\end{tabular}

Contudo, temos acesso a uma noção aproximada da realidade, o que nos permite retirar algumas ilações acerca da especialização dos ofícios, que naquele tempo eram cada vez mais qualificáveis em carreiras ${ }^{81}$, embora o conceito de carreira ainda estivesse longe de se aplicar ao caso da diplomacia.

Os valores abaixo apresentados permitem percecionar a quantidade de missões por homem. Contudo, o número de diplomatas que desempenharam a atividade de forma esporádica (ou seja, apenas uma, duas ou três vezes) é o mais significativo, conforme se pode observar na tabela 2 .

\footnotetext{
${ }^{80}$ MARINHO, Duarte de Babo - Os embaixadores portugueses..., Vol. 1, pp. 333-334.

${ }^{81}$ HOMEM, Armando Luís de Carvalho - "De João das Regras ao Conselho Régio...”, p. 1063.
} 
Tabela 2 - Relação quantidade de missões diplomáticas/número de diplomatas

\begin{tabular}{|c|c|c|}
\hline Número de missões & Número de diplomatas & \multirow{2}{*}{ Percentual } \\
\hline 1 & 19 & \multirow{2}{*}{$74,1 \%$} \\
\hline 2 & 11 & \multirow{2}{*}{} \\
\hline 3 & 10 & \multirow{2}{*}{$18,5 \%$} \\
\hline 4 & 4 & \\
\hline 5 & 2 & \\
\hline 6 & 2 & \multirow{2}{*}{$3,7 \%$} \\
\hline 7 & 1 & \\
\hline 8 & 1 & $3,7 \%$ \\
\hline 10 & 1 & \\
\hline 13 & 2 & \\
\hline Ind. & \multicolumn{2}{|c|}{} \\
\hline
\end{tabular}

Quanto aos homens que mais vezes participavam em missões, representam um núcleo duro que ostenta uma maior estabilidade e especialização no que respeita à diplomacia, principalmente nos finais do século XIV e ao longo do século XV. Cada um dos homens domina a praxis inerente à atividade que desempenha, ainda que intervalada com as suas diversas funções do dia-a-dia. Apesar de não se tratarem propriamente de profissionais da área, nem de as suas carreiras se esgotarem no exercício da diplomacia, destacavamse por terem uma sensibilidade muito mais apurada para essa prática, ao contrário de outros $^{82}$.

A veterania, ao nível da participação em missões de uma determinada natureza, ligava-se a uma maior familiaridade com as questões diplomáticas. O prolongamento das carreiras

\footnotetext{
${ }^{82}$ MORENO, Humberto Baquero - "O papel da diplomacia portuguesa no Tratado de Tordesilhas". Revista da Faculdade de Letras. História 12 (1995), pp. 135-150.
} 
nesta área refletia um vasto curriculum, que nos leva a entender que também o serviço na diplomacia era valorizado de acordo com a maior experiência que cada homem apresentava. Isto ajudou a dar resposta a um quadro diplomático mais alargado e que ia para além do seu âmbito tradicional (a Península Ibérica), desde finais do século XIV ${ }^{83}$. Por conseguinte, neste conjunto restrito de homens encontrámos alguns dos mais destacados membros da sociedade política quatrocentista, que desempenharam talentosamente variadíssimos serviços em prol da Coroa. Dessa forma, e em virtude desse talento individual, como refere Baquero Moreno, eram selecionados para as missões diplomáticas ${ }^{84}$.

\section{Considerações finais}

Como se pode observar ao longo deste texto, a Historiografia tem deixado bem clara a importância que a diplomacia assumiu para os Estados do ocidente europeu ao longo do século XV. Os poderes centrais tentaram criar as bases para uma gradual especialização dos serviços diplomáticos, aproveitando o dinamismo que se fazia sentir na burocracia régia ${ }^{85}$, ainda que com um ligeiro atraso relativamente a este organismo ${ }^{86}$. Há, contudo, casos concretos que nos demonstram, efetivamente, que os Estados tentaram criar condições para que tendencialmente a sua política externa fosse negociada por diplomatas cada vez mais especializados em determinadas questões e destinos ${ }^{87}$, demonstrando que tinham consciência das vantagens que podiam obter. Observando o contexto histórico daquele tempo encontrámos essas vantagens: Portugal manteve-se na vanguarda das práticas diplomáticas. Esta atenção não só permitiu ao reino tornar-se num dos principais vetores da política internacional e ser um dos seus intervenientes mais relevantes, como salvaguardar a sua independência face à cada vez maior força centrípeta de Castela ${ }^{88}$.

\footnotetext{
${ }^{83}$ MARINHO, Duarte de Babo - Os embaixadores portugueses..., Vol. 1, p. 336.

${ }^{84}$ MORENO, Humberto Baquero - "O papel da diplomacia portuguesa...", p. 143.

85 FREITAS, Judite de - O Estado em Portugal: (séculos XII-XVI): modernidades medievais. Lisboa: Alêtheia, 2012, pp. 22-32.

${ }^{86}$ AUTRAND, Françoise; CONTAMINE, Philippe - "Naissance de la France...", p. 271.

87 GANSHOF, François - Le Moyen Age. In RENOUVIN, Pierre (dir.) - Histoire des Relations Internationales. $3^{\mathrm{a}}$ Ed. Vol. 1. Paris: Librairie Hachette, 1964, pp. 267-268.

${ }^{88}$ MACEDO, Jorge Borges de - História Diplomática Portuguesa. Constantes e linhas de força. Estudo de Geopolitica. 2a . Ed. Lisboa: Tribuna/Instituto da Defesa Nacional, 2006, pp. 37-106.
} 
Contudo, e como temos salientado em outros estudos, continuamos da opinião que é essencial que a historiografia portuguesa aprofunde os trabalhos a respeito dos homens que representaram o reino internacionalmente, ao longo do século $\mathrm{XV}^{89}$. Esta necessidade deve-se ao facto de Portugal, naquele tempo, ser representado no exterior por indivíduos provenientes dos mais vários estratos da oficialidade régia (essencialmente veteranos com grande proximidade ao rei e à Corte). A origem social desses homens era variada, como variados eram os seus conhecimentos práticos e académicos. Tratava-se de especificidades essenciais e que serviam de justificação para que muitos desses homens marcassem presença, mais ou menos assídua, em inúmeras deslocações diplomáticas. $\mathrm{Na}$ verdade, a atuação das autoridades portuguesas da época potenciava um saber fazer diplomático; o que era de suma importância, pois evitava-se o recrutamento de homens sem experiência de negociação a nível internacional. Assim, de forma a não comprometer a honra do rei e do reino, garantia-se o máximo de eficácia na seleção do pessoal diplomático, com base em uma série de fatores determinantes ${ }^{90}$.

\footnotetext{
${ }^{89}$ MARINHO, Duarte de Babo - "Os agentes diplomáticos da Baixa Idade Média portuguesa (1431-1474): uma elite ao serviço da Coroa" ..., pp. 10-30. MARINHO, Duarte de Babo - "A atuação diplomática de Gomes Eanes e de Martim de Távora com vista à libertação do Infante D. Fernando (1439-1441)". Revista Mátria Digital 6 (2018), pp. 155-185.

${ }^{90}$ LOPES, Paulo - Um agente português na Roma do Renascimento. Lisboa: Temas e Debates/Círculo de Leitores, 2013, pp. 671-672.
} 


\section{Referências bibliográficas:}

\section{Fontes manuscritas}

Arquivo Nacional da Torre do Tombo, Chancelaria Régia, Chancelaria de D. Afonso V, Livro 9.

Biblioteca Nacional de França, Mss Lat. 6020.

Biblioteca Nacional de Portugal, Maço 226.

Biblioteca Pública de Évora, Fundo Manizola, Códice 177.

\section{Fontes impressas}

ÁLVARES, Fr. João - Trautado da vida e feitos do muiito vertuoso Sr. Infante D. Fernando. In Obras de Frei João Álvares. Ed. Adelino Almeida Calado. Vol. 1. Coimbra: Imprensa da Universidade, 1959-1960.

CHAVES, Álvaro Lopes de - Livro de apontamentos (1438-1489). Códice 443 da colecção Pombalina da B. N. L. Ed. Anastácia Mestrinho Salgado e Abílio José Salgado. Lisboa: Imprensa Nacional-Casa da Moeda, 1984.

DUARTE, Dom - Leal Conselheiro. Ed. Maria Helena Lopes de Castro e Afonso Botelho. Lisboa: Imprensa Nacional-Casa da Moeda, 1999.

DUARTE, Dom - Livro dos conselhos de el-rei D. Duarte. Livro da Cartuxa. Ed. A. H. de Oliveira Marques e João José Alves Dias. Lisboa: Editorial Estampa, 1982.

LIVRO Vermelho de D. Afonso V. In Collecção de livros ineditos da Historia portuguesa dos reinados de D. Affonso V a D. João II. Ed. José Correia Serra. Vol. 3. Lisboa: Academia Real das Sciencias, 1790-1793.

MONUMENTA Henricina. Ed. António Joaquim Dias Dinis. 15 vols. Coimbra: Comissão Executiva do V Centenário da Morte do Infante D. Henrique, 1960-1974.

ORDENAÇÕES Afonsinas. Ed. Mário Júlio de Almeida Costa e Eduardo Borges Nunes. $2^{\text {a }}$ Ed. 5 vols. Lisboa: Fundação Calouste Gulbenkian, 1998.

PORTUGUESE Abbot in Renaissance Florence. The letter collection of Gomes Eanes (1415-1463). Ed. Rita Costa Gomes. Firenze: Casa Editrice/Leo S. Olschki, 2017.

ZURARA, Gomes Eanes de - Crónica da tomada de Ceuta. Ed. Reis Brasil. Lisboa: Europa-América, 1992.

\section{Estudos}


ARAÚJO, Julieta - Portugal e Castela na Idade Média. Lisboa: Edições Colibri, 2009.

AUTRAND, Françoise - "Office et officiers royaux en France sons Charles VI (13881413)”. Revue Historique, 93 année, 242 (1969), pp. 49-64.

AUTRAND, Françoise; CONTAMINE, Philippe - "Naissance de la France: naissance de sa diplomatie. Le Moyen Âge". In Histoire de la diplomatie française. Du Moyen Âge à l'Empire. Vol. 1. Paris: Perrin, 2005, pp. 39-177.

BECEIRO PITA, Isabel - "La consolidación del personal diplomático entre Castilla y Portugal (1392-1455)". In III Jornadas Hispano-portuguesas de Historia Medieval. La Península Ibérica en la Era de los Descubrimientos (1391-1492). Vol. 2. Sevilla: Consejería de Cultura. Junta de Andalucía, 1997, pp. 1735-1744.

BECEIRO PITA, Isabel - "La importancia de la cultura en las relaciones peninsulares (siglo XV)". Anuario de Estudios Medievales [Em linha] 29 (1999), pp. 79-104. [Consultado a 12 de Julho de 2018]. Disponível em https://digital.csic.es/bitstream/10261/14366/1/20090630144606228.pdf.

BECEIRO PITA, Isabel - "La tendencia a la especialización de funciones en los agentes diplomáticos entre Portugal y Aragón (1412-1465)". In El Poder Real en la Corona de Aragón. XV Congreso de Historia de la Corona de Aragón. Vol. 2. Zaragoza: Gobierno de Aragón, 1994, p. 441-455.

BENNÀSSER, Pau - "Negociar la paz en el siglo XIV”. In COELHO, Maria Helena da Cruz; GOMES, Saúl António; RIBEIRO, Ângelo (ed.) - A Guerra e a sociedade na Idade Média. VI Jornadas luso-espanholas de estudos medievais. Eds. Maria Helena da Cruz Coelho, Saúl António Gomes e Ângelo Ribeiro. Vol. 2. Coimbra, 2009, pp. 16-28.

BRANCO, Maria João; FARELO, Mário - "Diplomatic Relations: Portugal and the Others". In MATTOSO, José (dir.) - The Historiography of Medieval Portugal: c. 19502010. Lisboa: Instituto de Estudos Medievais, 2011, pp. 231-259.

CAÑAS GÁLVEZ, Francisco de Paula - "La diplomacia castellana durante el reinado de Juan II: la participación de los letrados de la cancelaría real en las embajadas regias". Anuario de Estudios Medievales [Em linha] 40/2 (2010), pp. 691-722. [Consultado a 12 de Julho de 2018]. Disponível em http://estudiosmedievales.revistas.csic.es/index.php/estudiosmedievales/article/view/32 $\underline{1 / 325}$.

CÓRDOVA MIRALLES, Álvaro Fernández de - "Imagen de los Reyes Católicos en la Roma pontifícia". En la España Medieval [Em linha] 28 (2005), pp. 259-354. [Consultado a 12 de Julho de 2018]. Disponível em https://dialnet.unirioja.es/servlet/articulo? codigo $=1226611$.

FARELO, Mário - "La représentation de la couronne portugaise à Avignon et ses agents (1305-1377)". Anuario de Studios Medievales [Em linha] 40/2 (2005), pp. 723-763. [Consultado a 12 de Julho de 2018]. Disponível em https://dialnet.unirioja.es/servlet/articulo? codigo $=3332267$.

FARIA, Ana Leal de - “«Tu felix Austria nubes»”. In RODRIGUES, Ana Maria S. A; 
SILVA, Manuela Santos; FARIA, Ana Leal de (coord.) - Casamentos da Família Real Portuguesa. Vol. 1. Lisboa: Círculo de Leitores, 2017, pp. 57-77.

FARIA, Diogo; MARIANI, Andrea - "«Todos hão de ficar cegos»: 1'Italia di fine XV secolo osservata da un cardinale portoghese". Mediterranea - ricerche storiche, Ano 14 (dezembro 2017), pp. 695-706.

FARIA, Diogo - "Uma embaixada portuguesa do final da Idade Média: de Lisboa a Roma, 1443-1445”. Anuario de Estudios Medievales [Em linha] 48/2 (2018), pp. 695721. [Consultado a 9 de Setembro de 2018]. Disponível em https://research.unl.pt/ws/portalfiles/portal/12794762/901_916_1_PB.pdf.

FARIA, Diogo - "A participação de letrados laicos nas embaixadas portuguesas do final da Idade Média (1385-1495)”. In VIGIL MONTES, Néstor (dir.) - Comunicación política y diplomacia en la Baja Edad Media [Em linha]. Évora: Publicações do Cidehus, 2019 [Consultado a 1 de Julho de 2019]. Disponível em https://books.openedition.org/cidehus/7350 .

FARIA, Tiago Viúla de - "Pela "Santa Garrotea": Ofício cavaleiresco nas vésperas de Alfarrobeira". Actas do XIV Colóquio de História Militar: Portugal e os conflitos militares internacionais. Vol. 2. Lisboa, 2006, pp. 61-86.

FARIA, Tiago Viúla de - "Por prol e serviço do reino? O desempenho dos negociantes portugueses do Tratado de Windsor e suas consequências nas relações com Inglaterra (1384-1412)". Actas das VI Jornadas luso-espanholas de Estudos Medievais. A Guerra e a Sociedade na Idade Média. Vol. 2. SPEM, 2009, pp. 209-227.

FARIA, Tiago Viúla de - "Tracing the 'chemyn de Portynlage': English Service and Servicemen in Fourteenth-Century Portugal". Journal of Medieval History 37/3 (setembro 2011), pp. 257-268.

FERREIRA, Ana Maria - "O processo de Pedro Barreto contra Jean Forestier. Um episódio nas relações luso-francesas". Revisa da Faculdade de Letras de Lisboa 1 (1977), pp. 619-639.

FONSECA, Luís Adão da - O essencial sobre o Tratado de Windsor. Lisboa: Imprensa Nacional-Casa da Moeda, 1986.

FONSECA, Luís Adão da - D. João II. Mem Martins: Círculo de Leitores, 2005.

FREITAS, Judite de - O Estado em Portugal: (séculos XII-XVI): modernidades medievais. Lisboa: Alêtheia, 2012.

GANSHOF, François - Le Moyen Age. In RENOUVIN, Pierre (dir.) - Histoire des Relations Internationales. $3^{\text {a }}$ Ed. Vol. 1. Paris: Librairie Hachette, 1964.

GILLI, Patrick - "Bernard de Rosier et les débuts de la réflexion théorique sur les missions d'ambassade". In ANDRETTA, Stefano; PÉQUIGNOT, Stéphane; WAQUET, Jean-Claude (dir.) - De l'ambassadeur. Les éscrits relatifs à l'ambassadeur et à l'art de négocier du Moyen Âge au début du XIX siècle [Em linha]. Roma: Publications de l'École française de Rome, 2016 [Consultado a 12 de Julho de 2018]. Disponível em 
https://books.openedition.org/efr/2907.

GOMES, Saul António - D. Afonso V. O Africano. Mem Martins: Círculo de Leitores, 2006.

HESPANHA, António Manuel - História das instituições: época medieval e moderna. Coimbra: Almedina, 1982.

HOMEM, Armando Luís de Carvalho - "De João das Regras ao Conselho Régio: os legistas na afirmação da nova dinastia”. In DOMINGUES, Francisco Contente; HORTA, José da Silva; VICENTE, Paulo David (org.) - D'aquém, d'além e d'Ultramar: homenagem a António Dias Farinha. Vol. 2. Lisboa: Universidade de Lisboa. Faculdade de Letras/Centro de História, 2015, pp. 1061-1074.

HOMEM, Armando Luís de Carvalho - "Diplomacia e diplomatas nos finais da Idade Média a propósito de Lourenço Anes Fogaça, chanceler-mor (1374-1399) e negociador do Tratado de Windsor". In Actas do Colóquio Comemorativo do VI Centenário do Tratado de Windsor. Porto: Instituto de Estudos Ingleses da Faculdade de Letras da Universidade do Porto, 1988, pp. 221-240.

LALANDA, Maria Margarida - "A política externa de D. Afonso IV (1325-1357)". Arquipélago. História [Em linha] 11 (1989), pp. 107-151. [Consultado a 12 de Julho de 2018]. Disponível em https://repositorio.uac.pt/bitstream/10400.3/982/1/MariaMargaridaNogueiraLalanda p1 07-151.pdf.

LAZZARINI, Isabella - Communication and Conflict. Italian Diplomacy in the Early Renaissance, 1350-1520. Oxford: Oxford University Press, 2015.

LEROY, Béatrice - Du France parler en politique. Aimer et devoir écrire aux souverains en Castille au XV siècle. Limoges: Université de Limoges/Pulim, 2014.

LIMA, Douglas Mota Xavier de - "A política matrimonial de D. João I: um instrumento de afirmação dinástica. Portugal, 1387-1430”. Roda da Fortuna. Revista Eletrônica sobre Antiguidade e Medievo 3/2 (2014), pp. 191-209.

LIMA, Douglas Mota Xavier de - "Novos olhares sobre a diplomacia medieva". Revista Transversos 3 (2015), pp. 77-91.

LIMA, Douglas Mota Xavier de - A diplomacia portuguesa no reinado de D. Afonso $V$ (1448-1481). Niterói: Universidade Federal Fluminense, 2016. Tese de Doutoramento.

LIMA, Douglas Mota Xavier de - "Regal ceremonies and diplomatic practices. Contributions from the travel narratives from the 15th century". In VIGIL MONTES, Néstor (dir.) - Comunicación política y diplomacia en la Baja Edad Media [Em linha]. Évora: Publicações do Cidehus, 2019 [Consultado a 1 de Julho de 2019]. Disponível em https://books.openedition.org/cidehus/7453.

LOPES, Paulo - Um agente português na Roma do Renascimento. Lisboa: Temas e Debates/Círculo de Leitores, 2013. 
MACEDO, Jorge Borges de - História Diplomática Portuguesa. Constantes e linhas de força. Estudo de Geopolítica. 2a . Ed. Lisboa: Tribuna/Instituto da Defesa Nacional, 2006.

MAGALHÃES, José Calvet de - A Diplomacia Pura. Lisboa: Bizâncio, 2005.

MARINHO, Duarte de Babo - "A ação diplomática de Pedro Gonçalves de Malafaia na libertação do infante D. Pedro de Aragão (1432): antecedentes e significados". Revista Portuguesa de História, [Em Linha] 46 (2015), pp. 83-96. [Consultado a 12 de Julho de 2018]. Disponível em https://digitalisdsp.uc.pt/bitstream/10316.2/38184/1/A\%20acao\%20diplomatica $\% 20$ de $\% 20$ Pedro $\% 20$ Goncalves $\% 20 \mathrm{de} \% 20$ Malafaia.pdf?ln=pt-pt.

MARINHO, Duarte de Babo - Os embaixadores portugueses nos reinos ibéricos (14311474). Um estudo sociodemográfico. 2 vols. Porto: Faculdade de Letras da Universidade do Porto, 2017. Tese de Doutoramento.

MARINHO, Duarte de Babo - "Os agentes diplomáticos da Baixa Idade Média portuguesa (1431-1474): uma elite ao serviço da Coroa". História: Revista da Faculdade de Letras da Universidade do Porto [Em linha] 7/2 (2017), pp. 10-30. [Consultado a 12 de Julho de 2018]. Disponível em https://ler.letras.up.pt/uploads/ficheiros/16032.pdf.

MARINHO, Duarte Babo - "Diplomacia visual na Baixa Idade Média portuguesa: os oficiais de armas". Medievalista [Em linha] 24 (julho-dezembro 2018) [Consultado a 12 de Julho de 2018]. Disponível em http://www2.fcsh.unl.pt/iem/medievalista/MEDIEVALISTA24/marinho2404.html

MARINHO, Duarte de Babo - "A atuação diplomática de Gomes Eanes e de Martim de Távora com vista à libertação do Infante D. Fernando (1439-1441)". Revista Mátria Digital 6 (2018), pp. 155-185.

MARINHO, Duarte de Babo - "Recensão de Diplomatie et «Relations Internationales»" au Moyen Âge (IXe-XVe siècle)". História: Revista da Faculdade de Letras da Universidade do Porto [Em linha] 9/1 (2019), pp. 235-238. [Consultado a 1 de Julho de 2019]. Disponível em https://ojs.letras.up.pt/index.php/historia/article/view/6167/5809.

MARINHO, Duarte de Babo. COSTA, Paula Pinto. MARIA CRISTINA, Cunha "Preparation of embassies and protocol followed by royal Portuguese ambassadors in late-medieval times". E-Journal of Portuguese History [Em linha] 1/17 (2019). [Consultado a 1 de Julho de 2019]. Disponível em https://www.brown.edu/Departments/Portuguese_Brazilian_Studies/ejph/forth.html.

MARINHO, Duarte de Babo - "Diplomacia e espionagem na baixa Idade Média portuguesa". In VIGIL MONTES, Néstor (dir.) - Comunicación política y diplomacia en la Baja Edad Media [Em linha]. Évora: Publicações do Cidehus, 2019 [Consultado a 1 de Julho de 2019]. Disponível em https://books.openedition.org/cidehus/6946.

MATTINGLY, Garrett - Renaissance Diplomacy. Baltimore: Penguin Books, 1964.

MENDONÇA, Manuela - "Diplomatas portugueses na costa africana (1434-1495: uma releitura de João de Barros)". Mare Liberam: revista de história dos mares 10 (1995), pp. 341-353. 
MENDONÇA, Manuela - "Portugal na Christiana Respublica". In SOARES, Nair de Nazaré Castro; LÓPEZ MOREDA, Santiago - Génese e consolidação da Ideia de Europa. Idade Média e Renascimento. Vol. 4. Coimbra: Imprensa da Universidade de Coimbra, 2009, pp. 61-82.

MIRANDA, Flávio - Portugal ant the Medieval Atlantic. Commercial Diplomacy, Merchants, and Trade, 1143-1488. Porto: Faculdade de Letras da Universidade do Porto, 2012. Tese de Doutoramento.

MOEGLIN, Jean-Marie e PÉQUIGNOT, Stéphane (dir.) - Diplomatie et «Relations Internationales» au Moyen Âge (Ix $-X V^{e}$ siècle). Paris, Press Universitaires de France, 2017.

MONTEIRO, Nuno Gonçalo; CARDIM, Pedro - "La Diplomacia durante el Antiguo Régimen. Perfil sociológico y trayectorias". Cuadernos de Historia Moderna [Em linha] 30 (2005), pp. 7-40. [Consultado a 12 de Julho de 2018]. Disponível em https://revistas.ucm.es/index.php/CHMO/article/view/CHMO0505110007A/22171.

MORENO, Humberto Baquero - "O papel da diplomacia portuguesa no Tratado de Tordesilhas". Revista da Faculdade de Letras. História [Em linha] 12 (1995), pp. 135150. [Consultado a 12 de Julho de 2018]. Disponível em https://repositorioaberto.up.pt/bitstream/10216/7845/2/2025.pdf.

MOTA, Eugénia Pereira da - Do Africano ao Príncipe Perfeito: (1480-1483). Caminhos da burocracia régia. Vol. 1. Porto: Faculdade de Letras da Universidade do Porto, 1989. Dissertação de Mestrado.

NIETO SORIA, José Manuel - Iglesia y génesis del Estado Moderno en Castilla (13691480). Madrid: Editorial Complutense, 1993.

NOGALES RINCÓN, David - "La cultura del pacto en las relaciones diplomáticas lusocastellanas durante el periodo Trastámara (1369-1504)". En la España medieval [Em linha] 35 (2012), pp. 121-144. [Consultado a 12 de Julho de 2018]. Disponível em https://dialnet.unirioja.es/servlet/articulo? codigo $=3986849$.

OCHOA BRUN, Miguel Ángel - "Los usos diplomáticos en la época del Tratato de Tordesillas". In El Tratado de Tordesillas y sy Época. Congreso Internacional de Historia. Vol. 2. Junta de Castilla y León, 1995, pp. 801-824.

OLIVERA SERRANO, Cesar - "Servicio al rey y diplomacia castellana: Don Juan Manuel de Villena (1462)". Anuario de Estudios Medievales, [Em linha] 25 (1995), pp. 463-488. [Consultado a 12 de Julho de 2018]. Disponível em http://digital.csic.es/bitstream/10261/17263/1/20090717140926228.pdf.

PÉQUIGNOT, Stéphane - "Les diplomaties occidentales, XIII"-XV" siècles, dans les relations diplomatiques au Moyen Âge”. In Formes et enjeux. Paris: Publications de la Sorbonne, 2011, pp. 47-66.

PÉQUIGNOT, Stéphane - "Les instructions aux ambassadeurs des rois d'Aragon (XIIIXV siècles). Jalons pour l'histoire de la fabrique d'une parole royale efficace". Cahiers d'études hispaniques médiévales, 31 (2008), pp. 17-43. 
PÉQUIGNOT, Stéphane - Au nom du roi. Pratique diplomatique et pouvoir durant le règne de Jacques II d'Aragon (1291-1327). Madrid: Bibliothèque de la Casa Velázquez, 2009.

RAMIREZ VAQUERO, Eloísa - "Estrategias diplomáticas de rey de Navarra en el tránsito al siglo XV. In XXXI Semana de Estudios Medievales. Pamplona: Gobierno de Navarra/Departamento de Cultura y Turismo/Institución Príncipe de Viana, 2005, pp. 373-421.

RAMOS, Manuel - Orationes de Jean Jouffroy em favor do Infante D. Pedro (14491450). Retórica e Humanismo cívico. Porto: Faculdade de Letras da Universidade do Porto, 2006. Tese de Doutoramento.

RODRIGUES, Ana Maria S. A. - "Casamentos régios na Idade Média: um feixe de problemas". In RODRIGUES, Ana Maria S. A.; SILVA, Manuela Santos; FARIA, Ana Leal de (coord.) - Casamentos da Família Real Portuguesa. Vol. 1. Lisboa: Círculo de Leitores, 2017, pp. 35-56.

RUSSELL, Peter - A intervenção inglesa na Península Ibérica durante a Guerra dos Cem Anos. Lisboa: Imprensa Nacional da Casa da Moeda, 2000.

SANTOS, Maria Alice - A sociologia da representação político-diplomática no Portugal de D. João I. Lisboa: Universidade Aberta, 2015. Tese de Doutoramento.

SOUSA, Armindo de - As cortes medievais portuguesas: 1385-1490. 2 vols. Porto: INIC, 1990.

VAZ, Vasco Rodrigo dos Santos Machado - A boa memória do monarca. Os escrivães da Chancelaria de D. João I (1395-1433). Vol. 1. Porto: Faculdade de Letras da Universidade do Porto. 1995. Dissertação de Mestrado.

VIGIL MONTES, Néstor - "«Tractados de pazes, aliança e concordia entre as duas coroas de Portugal e Inglaterra», un cartulario realizado a comienzos del siglo XV para consolidar el Tratado de Windsor entre los reinos de Inglaterra y Portugal (1386), la alianza permanente más prolongada de la historia". Espacio, Tiempo y Forma. Revista de la Facultad de Geografía e Historia [Em linha] 32 (2019), pp. 469-498. [Consultado a 1 de Julho de 2019]. Disponível em http://revistas.uned.es/index.php/ETFIII/article/view/22403/19166.

VIGIL MONTES, Néstor - "El rumor político en diplomacia: la especulación sobre el posible destino de la armada portuguesa que se estaba preparando para finalmente conquistar Ceuta (1411-1415)". In VILLARROEL GONZÁLEZ, Óscar, GARCÍA ISAAC, José Marcos, y CHELLE ORTEGA, José Antonio (eds.) - Guerra y Diplomacia en la Península Ibérica (1369-1474). Madrid: La Ergástula, 2019, pp. 15-40.

VIGIL MONTES, Néstor - "Diplomacia y diplomática: un análisis de las fuentes documentales de la diplomacia bajomedieval". In VIGIL MONTES, Néstor (dir.) Comunicación política y diplomacia en la Baja Edad Media [Em linha]. Évora: Publicações do Cidehus, 2019. [Consultado a 1 de Julho de 2019]. Disponível em https://books.openedition.org/cidehus/6880. 
VIGIL MONTES, Néstor - "A modo de introducción: nuevos caminos de la historiografía sobre la diplomacia medieval”. In Comunicación politica y diplomacia en la Baja Edad Media. Dir. Néstor Vigil Montes. Évora: Publicações do Cidehus, 2019. [Consultado a 1 de Julho de 2019]. Disponível em https://books.openedition.org/cidehus/7438.

VILLANUEVA MORTE, Concepción - "La correspondencia diplomática entre los embajadores del ducado de Milán y la corte de los reinos hispánicos en la segunda mitad del siglo XV". In Dossier la sociedad cortesana en la Península Ibérica (siglos XIV-XV): fuentes para su estudio. Madrid: Bibliothèque de la Casa Velázquez, 2015, pp. 143-166.

WATKINS, John - "Toward a New Diplomatic History of Medieval and Early Modern Europe". Journal of Medieval and Early Modern Studies [Em linha] 38/1 (2008), pp. 114. [Consultado a 8 de Outubro de 2019]. Disponível em https://read.dukeupress.edu/jmems/issue/38/1.

\section{COMO CITAR ESTE ARTIGO}

\section{Referência electrónica:}

MARINHO, Duarte Maria Monteiro de Babo - "A diplomacia e os diplomatas na baixa Idade Média portuguesa (1431-1475)”. Medievalista 27 (Janeiro-Junho 2020). [Em linha] [Consultado dd.mm.aaaa]. Disponível em http://www2.fcsh.unl.pt/iem/medievalista/MEDIEVALISTA27/marinho2707.html ISSN 1646-740X. 
A diplomacia e os diplomatas na baixa Idade Média portuguesa (143/-1475) - Duarte Babo Marinho

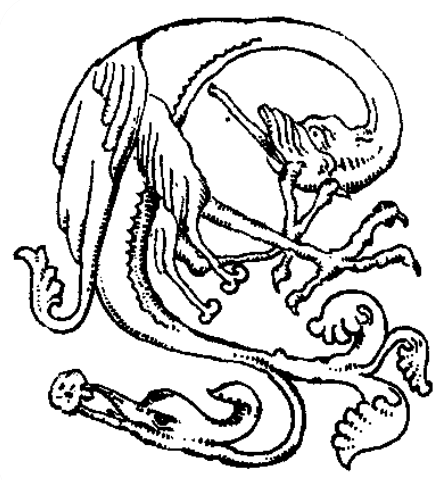

